\title{
Fracture of Ulna Related to Birth
}

National Cancer Institute

\section{Source}

National Cancer Institute. Fracture of Ulna Related to Birth. NCI Thesaurus. Code C116828.

A broken ulna sustained during the birthing process. 